\title{
The impact of strategy alignment on organisational performance in national public entities in the Northern Cape Province of South Africa
}

Author:
Moses M. Gasela1 10
Affiliation:
'Department Business
Management, Faculty
Economics and Management
Sciences, Free State
University, Kimberley,
South Africa
Corresponding author:
Moses Gasela,
2013088543@ufs4life.ac.za
Dates:
Received: 30 Aug. 2020
Accepted: 04 Dec. 2020
Published: 04 Mar. 2021
code with your
How to cite this article:
Gasela, M.M., 2021, 'The
impact of strategy alignment
on organisational
to read online.
performance in national
public entities in the
Northern Cape Province of
South Africa', Africa's
Public Service Delivery and
Performance Review
9(1), a489. https://doi.
org/10.4102/apsdpr.v9i1.489
Copyright:
C 2021. The Authors.
Licensee: AOSIS. This work
is licensed under the
Creative Commons
Attribution License.

Background: South African national public entities play a significant role in the economy as they assist government to achieve the public service delivery mandate. However, these entities are facing numerous problems and challenges including a misalignment between corporate (i.e. government department) and business strategies of business units. The impact these problems and challenges have on organisational performance and hence service delivery, and why the misalignment exists are not known. Hence, this study was intended to fill this gap.

Aim: This study was intended to analyse the extent of misalignment or alignment between corporate- and business-level strategies and the resulting impact on organisational performance in schedule 3 public entities in the Northern Cape Province of South Africa (SA).

Setting: The public sector entities at the local, provincial and/or national level, in terms of culture, legal framework, structure, linkages and, especially, performance as it relates to the topic, political dynamics.

Method: The survey design and the multicase study design with mixed methods (i.e. qualitative and quantitative methods) were applied. A semi-structured questionnaire was used to collect data from 38 randomly selected executives of public entities and provincial government, and in-depth interviewing was used to collect qualitative data. Multiple regression and thematic analysis were used to analyse the data.

Results: It was found that a misalignment between the corporate- and business-level strategies in SA public entities caused by, amongst others, lack of capacity and ineffective communication, negatively affects the strategy implementation, hence causing service delivery problems.

Conclusion: The misalignment between the corporate- and business-level strategies affects the strategy implementation, hence affecting the service delivery negatively. This gap should be minimised by addressing the problems and challenges faced by the public entities such as lack of human resources capacity and ineffective communication in order to enhance organisational performance.

Keywords: strategy alignment; business-level strategy; corporate-level strategy; organisational performance; SA public entities.

\section{Introduction}

Public entities worldwide contribute approximately 10\% of the world's Gross Domestic Product (GDP) and account for a substantial proportion of employment as well as assets in many countries (Peng et al. 2016:1; Putnins 2015:815). Furthermore, the public entities in the economies of BRICS member states, consisting of Brazil, Russia, India, China and South Africa (SA), play significant roles. According to Stan, Peng and Bruton (2014:474) and Ying, Deng and Liu (2016:121), stock market capitalisation of public entities represent $80 \%$ of China's, $62 \%$ of Russia's and 38\% of Brazil's stock market capitalisation. In SA, when delivering the 2016 national budget speech, the Finance Minister stated that SA public entities play an important and unique role as they assist the SA government to meet its service delivery mandates in different sectors of the economy. The minister also noted that, compared to profit-orientated organisations, the entities have an additional motive to boost economic growth and the broader development of SA through a combined 'asset base of over R1 trillion, equivalent to about $27 \%$ of GDP' (SA National Treasury budget speech 2016:18). The asset base of the SA public entities approximates $62 \%$ of the $2018 / 2019$ 
national budget. 'Public entities' are organisations that are controlled by the state, through a majority or $100 \%$ shareholding, in order to achieve certain service delivery strategic objectives of the state in the key sectors of the economy. They have a mandate to fulfil a specific economic or social responsibility of government. They rely on government funding and public money, either by means of a transfer from the revenue fund or through statutory money.

All SA public entities are required to comply with applicable laws and regulations such as the Public Finance Management Act (PFMA) and have both national sector (corporate) strategies and official master plans governing their mandates and scope, which are guided by these Acts when executing their mandates. Notwithstanding the significance of the SA public entities to the economy, the study was conducted at the backdrop of service delivery and performance problems that are currently being experienced by some SA public entities. There are inefficiencies in terms of staffing and financing of the SA public entities that increase the costs of key inputs and fiscal challenges in the SA economy. Finally, the aforesaid bailouts also contributed to the deterioration of the SA debt-to-GDP ratio to over 50\% in 2017. Hence, even though public entities are playing a significant role in assisting the SA government to achieve the public service delivery mandate, they are experiencing huge service delivery problems. Amongst these problems, according to the literature (Andrews et al. 2012:79; Carvalho, Francisco \& Paulo 2017:119; Musuka 2006:62; Schniederjans \& Cao 2009:2535; Sull et al. 2018a:130; Van Riel 2008:351), is the seemingly non-alignment of corporate and business strategies of business units, which is affecting organisational performance. The extent to which this misalignment of strategies is affecting organisational performance, and hence public service delivery, and why it exists are not known; of all the studies that have been done on this topic, none have specifically investigated the misalignment between the strategies and given the reasons why it exists in SA public entities. This study was intended to fill this gap.

The organic system theory, resource-based theory and agency theory underpinned this study. According to Van Deusen et al. (2007:75), organisations resemble organic systems as they go through a life cycle from birth, through growth, maturity, decline, and finally ceases to exist (death). At their decline in the life cycle, organisations should use renewal corporate strategies such as turnaround or restructuring to revive their fortunes in trying to meet their strategic objectives. Van Deusen et al. (2007:75) and Volberda et al. (2011:166) confirmed that one of the advantages of pursuing certain types of corporate-level strategy is increased market power of the organisation, which implies growth. Pursuance of diversification by an organisation in a stagnant or declining industry is also an appropriate strategic response to ensure organisational growth (Grant 2010:354). The additional benefit of a corporate strategy is that it enables the organisation to overcome the barriers to entry in the industry (Ireland et al. 2011:179).
With reference to the resource-based theory, using unique resources and capabilities increases the competitive position of the organisation in the industry (Coulter 2002:256) as a result of pursuing certain corporate-level strategies. The resource-based view focuses on the internal capabilities and resources of the organisation as a source of competitive advantage, which is in contrast with Porter's (1980) perspective which focuses on the industry forces as a source of competitive advantage (Galvin, Rice \& Liao 2014:250; Wang 2017:1068). Firmansyah (2015:667) found that the resources of the organisation influence the organisational performance (see also Mbo \& Adjasi 2017a:960, 2017b:405). According to the studies done in Botswana by Mbo and Adjasi (2017a:960, 2017b:405), the resources of an organisation such as finance and leadership (board strength) influence performance positively.

Giachetti (2012:1057) supported the notion that the pursuance of certain corporate-level strategies such as high diversification is attributable to the resources of the organisation that are distinct and superior competencies of its top management. In two different studies, unlike this study, in Botswana and SA, Mbo and Adjasi (2017a:960, $2017 \mathrm{~b}: 405)$ investigated the drivers of organisational performance in state-owned enterprises and found that the resources of an organisation such as finance as well as leadership (board strength) influence performance positively. Matsusaka (2003:428) argued that organisations search for strategic business units through pursuance of certain corporate-level strategies to ensure that their organisational resources and capabilities (i.e. marketing, distribution, top and middle management skills, etc.) are put into productive use in those business units. An organisation with the abovementioned valuable capabilities will seek new strategic business units that match its valuable resources and capabilities to develop them (Matsusaka 2003:410). The core principles of the resource dependence theory stipulate that the control by the head office to its units is easy when the unit is dependent on the head office for the key resources it requires.

Regarding the agency theory, Doukas and Kan (2008:1485) found that one of the key disadvantages of pursuing a corporate strategy by organisations is agency-related problems as a result of managers in strategic business units having interests and goals that differ from those of parent department managers, resulting in the misalignment between the two. Furthermore, according to Doukas and Kan (2008:1485), managers of organisations sometimes use corporate-level strategies for various reasons, including pursuit of growth, to diversify by creating complex diversified organisations, which are detrimental to the interests of shareholders. From the agency theory perspective, pursuance of certain corporate-level strategies of organisations can be explained as an attempt by the management of the parent department to advance their personal interests such as power, good salaries, influence and goals at the expense of shareholders (Martin \& Sayrak 2003:40). In SA, systemic corruption has become the norm as 
evidenced in the recent Transparency International's Corruption Index. During the Zuma administration, the scale and magnitude of corruption intensified, and the term 'state capture' was used to describe this phenomenon. The institutionalisation of endemic corruption in SA is like a silent coup; a political project granted legitimacy under the radical economic transformation project enforced by the SA government.

This study aimed to analyse the implementation of corporateand business-level strategies, and the misalignment between them; and to find out why and how it exists, and subsequently recommend improvement-enhancing mechanisms to strategise implementation and alignment amongst them in the public entities of SA.

The article is organised as follows: after the Introduction section, Literature Review section is presented, followed by Research Design and Methodology section, and finally, the Results section. The article ends with a discussion of the findings, conclusions and recommendations.

\section{Literature review Definition of terms}

For the purpose of this study, business-level strategy refers to competitive moves and actions by the SA entities in specific markets, aimed at effective service delivery and the realisation of predetermined objectives and mandates as contained in the strategic plans (Volberda et al. 2011:166). According to Volberda et al. (2011:166), business-level strategy is defined as an 'integrated and coordinated set of commitments and actions a firm uses to gain competitive advantage by exploiting core competencies in specific product markets'. Hough et al. (2008:5) suggested that competitive moves and actions of a business-level strategy in the market place have the sole purpose of improving financial performance, strengthening the long-term competitive position and gaining a competitive edge over rivals.

Like in the case of business-level strategy, there is no unanimously or universally accepted definition of a corporate-level strategy (Higgins 2005:5; Jooste et al. 2008:4; Volberda et al. 2011:166). Jooste et al. (2008:4), and the Association of Chartered Certified Accountants (2012:10) defined corporate-level strategy as the 'direction and guidance by headquarters to its individual businesses/ divisions on overall purpose and scope'. A fundamental issue in the corporate-level strategy of an organisation is referred to by Picone and Dagnino (2011:5) as a 'choice of scope' of the organisation. Scope of an organisation involves, according to Bowman and Helfat (2001:1), the selection of industries to compete for its business units. For the purpose of this study, corporate-level strategy of an SA entity was defined as the overall organisation-wide business scope and purpose within broad objectives stipulated in the founding applicable enabling the Act of parliament. All business-level strategies of different business units within each SA public entity flow from a defined corporate-level strategy. A misalignment between corporate strategies and businesslevel strategies exists when corporate strategies are not in sync with the strategies of business units.

\section{Alignment between corporate- and business-level strategies}

South African public entities are required to comply with applicable laws and regulations. For example, they are required to produce various financial and service delivery reports, indicating their performance for compliance and accountability purposes to the public, as required by the following directives and legislation: PFMA (1999); relevant enabling founding legislation for entities such as the Northern Cape Economic Development, Trade and Investment Promotion Agency (NCEDA) Act no. 4 of 2008 and Northern Cape Gambling Act no. 3 of 2008 for NCEDA as well as the Northern Cape Gambling Board, respectively; National Treasury Regulations (2005), and Framework for Strategic Plans and Annual Performance Plans (2010).

The alignment of strategy is a process which impacts on all levels and members of the organisation (Musuka 2006:62). Based on the research conducted thus far, there seems to be an academic consensus amongst authors such as Schniederjans and Cao (2009:2535) and Seifzadeh (2013:148) that an alignment or non-alignment of corporate-level strategy and business-level strategy of business units or divisions affects organisational performance. In his study of the effect of corporate-level strategy on business-level strategy, Seifzadeh (2013:148) found that a fit between corporate strategy and business unit strategy has a significant effect on the business unit financial performance. This study was done on industrial development in Iranian organisations. A study of 176 organisations in the commerce industry by Schniederjans and Cao (2009:2535) concluded that the alignment of strategies is presumed to be a positive contributor to organisational performance, just as misalignment is presumed to be a negative contributor to organisational performance. The reason for this is that aligned organisations are better equipped to increase internal synergy and consequently, better qualified to orchestrate activities across all company's departments, resulting in an increased competitive advantage (Van Riel 2008:351).

Conducting the study from a somehow different perspective of a balanced scorecard compared to all the previous studies, Ito and Souissi (2012:63) used the data from the case study investigations of different Japanese organisations and found that aligned strategies create organisational value. These results echoed the earlier findings which found that aligned strategies influence performance positively. The positive relationship between aligned strategies and organisational performance was further supported by an exploratory study in Brazilian steel mills by Carvalho et al. (2017:119). Also, it was found that organisations with aligned strategies have a better organisational performance compared to organisations 
which have strategy misalignments. Approaching the effect of alignment between the corporate- and business-level strategies on organisational performance from a publicsector perspective, Andrews et al. (2012:79) explored the alignment effect of different levels of strategies on organisational performance in British local governments. Andrews et al. (2012:79) examined the effects of vertical strategic alignment (i.e. the degree to which strategic stances are consistent across different organisational levels) on public service performance and found evidence of a positive influence of aligned strategies at different organisational levels on organisational performance. Unlike the present study, the study was a longitudinal multivariate analysis undertaken on a panel of public organisations over four years.

\section{Strategy alignment and implementation}

In their study on the role of marketing managers' commitment and involvement in marketing strategy implementation, Ramaseshan, Ishak and Rabbanee (2013:465) argued that effective strategy implementation assists the organisation to achieve its strategic goals and that, with better implementation, even inappropriate strategies may yield better results compared to good and appropriate strategies that are implemented poorly. This is compatible with Ali and Hadi's (2012:265) estimation that about two-thirds of good and well-conceived strategies of organisations are not implemented effectively. According to Cristian-Liviu (2013:1690), Lowy (2015:18) as well as Prasad et al. (2018:6), lack of resources is one of the challenges that cause problems when implementing a strategy (see also Reitsma \& Hilletofth 2018).

Monauni (2017:1) and Sull, Homkes and Sull (2015:4) were of the opinion that a breakdown in communication between key role players responsible for ineffective strategy implementation (Sull et al. 2018a:130) and a lack of information are the key challenges in strategy implementation and hence affect organisational performance negatively (Sull et al. 2015:4, 2018a:130).

Approaching strategy implementation from a different perspective, Balashova and Gromova (2016:326), Firmansyah (2015:667), Kogo and Kimencu (2018:132) and Sull et al. (2017b:2) were of the opinion that an organisation's resources are its most valuable assets during strategy implementation, which lead to its competitive advantage and improved performance.Studyingstrategy-executionand implementation, Sull et al. (2015:4, 2017a:5, 2017b:2) claimed that the lack of strategy-alignment leads to weak strategy implementation. Of all the research studies reviewed, none of them answered the following questions: if alignment gaps exist between the two-level strategies in public entities, why do they exist and how can they be minimised? To what extent, if any, do the alignment gaps exist between the two-level strategies in SA public entities? What is the extent of implementation of strategies in public entities? Hence, this study was intended to answer them.

\section{Research design and methodology}

The study was done in the Northern Cape Province, and the following eight public entities were studied as cases: Kalahari Kid Corporation (KKC), NCEDA, Northern Cape Gambling Board, Northern Cape Liquor Board, Northern Cape Tourism Authority (NCTA), McGregor Museum, Northern Cape Arts and Culture Council and Ngwao-Boswa Ya Kapa Bokone. The aforesaid public entities fall within divergent industries such as tourism, sports, economic development, heritage, gambling and hospitality. Furthermore, the above mentioned public entities report to the following three departments, namely Department of Economic Development and Tourism (DEDT), Department of Agriculture and Land Reform (DALR) and Department of Sports and Culture (DSC). In the context of this study, the above-mentioned three provincial departments can be regarded as the corporate parents of the eight public entities. According to Gold, Campbell and Alexander (1994:1), a corporate parent refers to an organisation that controls another entity through various influence mechanisms such as the appointment of directors and financial linkages. The DEDT controls NCEDA, NCTA, Northern Cape Gambling Board and the Northern Cape Liquor Board. Kalahari Kid Corporation is controlled by the DALR. Macgregor Museum, Northern Cape Arts and Culture Council and Ngwao-Boswa Ya Kapa Bokone are controlled by the DSC.

Based on the nature of the topic and the research objectives and questions, this study was positioned within the postpositivist and interpretivist-constructivist paradigms. In concurrence with the adopted post-positivist, constructivist and interpretivist research paradigms, the concurrent mixedmethods design was used in the study (Creswell 2008:4), and this created complementary data gathering activities that compensated for the weaknesses of the individual techniques of either quantitative or qualitative methods (Ostlund et al. 2011:369; Torrance 2012:113).

A combination of the survey design and multicase study design was used in this study (see Bikson 1991:323; Gutek 1991:317). Using this combination of approaches, there was potentially great power, which provided both breadth and depth of analysis within a single investigation. The qualitative wealth of detailed information about a smaller number of people and cases increased the understanding of the issues that were investigated in this study. Hence, both deductive and inductive approaches were adopted for the investigation (Saunders, Lewis \& Thornhill 2009:1).

\section{Population and sample}

The target population for the study was all schedule 3 public entities in the Northern Cape Province. The study sample consisted of eight public entities and three provincial government departments, whose executives provide direct control to those public entities in the Northern Cape Province. The executives of the eight entities and the three provincial governments, that is, DEDT, DALR and DSC were the 
respondents. The executives in the public entities are responsible for crafting and implementing business-level strategies that are supposed to be aligned with corporatelevel strategies. The executives from the head offices of the three provincial departments are responsible for the crafting of corporate-level strategies of the public entities that are under their control. In addition to crafting corporate-level strategies of the public entities, the executives from the three provincial departments must ensure that the business-level strategies of the public entities are aligned to the corporatelevel strategies.

The simple random sampling method was applied to select the respondents for the quantitative component of the study. The sample consisted of four executives from each of the eight public entities (eight public entities $\times$ four executives per public entity $=32$ ). The selected executives provided their views on the influence of the aligned corporate- and business-level strategies to organisational performance. The sample also included two executives from each of the head offices of the aforesaid three provincial government departments which provide direct control to the eight public entities, through the appointment of the board of directors of those entities. The executives gave their views and perceptions on corporate- and business-level strategy alignment issues from the corporate parent's perspective as well. Therefore, a total of six executives (two executives $x$ three departments) from the provincial departments formed part of the sample of respondents. The total size of the sample for the quantitative investigation was 38 respondents (32 from the entities and six from the controlling provincial departments).

The purposive sampling method was used to select the participants that were interviewed in the qualitative investigation of the study (Silverman 2000). Eleven executives from the SA public entities and their controlling provincial departments were purposively selected as participants because these executives are responsible for the alignment of the public entity's business-level strategies to the corporate-level strategies. Furthermore, the executives from the relevant provincial departments monitor the alignment of the crafted corporate-level strategies with the business-level strategies of the public entities and the executives of the public entities monitor the strategy implementation in their entities. The participants of the qualitative research were different from the respondents who were selected for the quantitative research, purposely to compare the findings between the two to increase the reliability and validity of the study findings.

\section{Data collection}

For the quantitative component of the investigation, a selfadministered questionnaire was emailed to all 38 executives as respondents for the purposes of collecting data. The 5-point Likert scale was used in the survey questions. For the qualitative component, interviews, strategy documents and annual reports of the public entities were the data collecting instruments of the study. In addition, data were also obtained from the strategic documents and annual reports of the public entities.

\section{Data analysis}

The Statistical Package for Social Scientists (SPSS) was used to analyse the quantitative data. Descriptive and inferential statistical analyses were done. The response rate was $78 \%$. Descriptive and inferential statistical analyses (using multiple regression analysis) were done to address some of the research objectives. Data analysis for the qualitative data involved organising the details about a case (in this study, the entity), categorising of data and compiling it into meaningful groups, and identifying of patterns and/or trends and themes. Then, the researcher synthesised and generalised data, giving an overall portrait of the case, with a conclusion and implication beyond the case. The researcher looked for convergence with the content analysis of the official strategic documents of the public entities. A similar approach was followed in the document analysis of approved official strategic documents, which complemented the analysis of data that was collected through the individual interviews.

\section{Reliability and validity}

Triangulation was used to ensure the reliability and validity of the study findings, through divergent mixedmethods. Different sample members were subjected to the interview and questionnaire. Pilot testing of the questionnaire was also undertaken. Ten executives from the public entities and the controlling provincial departments participated in the pilot study, and these were not used in the main study sample. They were asked to provide feedback to the researcher on the questions that seemed to be vague and not easily understandable, requiring further explanation. Their comments and feedback were incorporated in the final questionnaire that was sent to respondents.

\section{Ethical considerations}

An approval to conduct this study was obtained from the Faculty of Economic and Management Sciences Research Committee of the University of Free State. Approvals were also obtained from the CEOs of the eight public entities to conduct the study in those entities. Furthermore, approvals to conduct the study were received from the heads of department of the three provincial departments that are controlling the eight public entities. Respondents in this study signed a written informed consent form indicating their voluntary participation. It should be noted that the strategic documents and annual reports of the public entities which were used in the content analysis are publicly available documents on the respective websites (Ethical clearance number: UFS-HSD2018/0003). 


\section{Results}

This section presents the results of the study. It consists of two sub-sections: Demographic Information section presents the demographic information of the respondents, and Inferential Analysis section provides the results pertaining to the research objective.

\section{Demographic information}

The majority were in the age group of 35-44 (50\%), and most respondents were males $(73.3 \%)$. Far more males $(72.4 \%)$ than females were interviewed, which might be an indication that gender discrimination is still being practiced in the workplace in SA (because the executives in public entities are predominantly males). Most respondents (93.34\%) had less than 20 years of management experience and almost all the respondents $(96.67 \%)$ had either a degree or a diploma and a management qualification. This implies that the managers had the relevant knowledge to execute their duties.

\section{Inferential analysis}

\section{The relationships between strategy alignment and organisational performance}

Multiple regression modelling was used to determine the relationships between strategy alignment (corporate- and business-level strategies) and leadership (i.e. independent variables), and organisational performance (i.e. dependent variable). With reference to Table 1 , the fitted model was highly significant (prob. $=0.000<0.01$ ) at the $1 \%$ level. The results indicate that strategy alignment $(t=2.37$, prob. $=$ $0.025<0.05)$ and leadership $(t=2.95$, prob. $=0.007<0.01)$ were significant at the $5 \%$ level and $1 \%$ level respectively. Hence, strategy alignment and leadership affect organisational performance positively. The adjusted $R$-square was 0.954 , which means that the model explained $95.4 \%$ of the total variation of organisational performance. It should be noted that strategy implementation was not included in the model to avoid the potential multicollinearity problem.

\section{The relationship between corporate- and business-level strategies at public entities}

It was found that the business-level strategies were in line with the corporate strategies and seemingly, there was a good relationship between the two sets of strategies. However, for almost all the public entities, this existed only on paper. Practically, the relationship was not good; there were alignment gaps between the two sets of strategies and the entities did not implement their strategies as they should. There were many reasons for this, which ranged from the lack of capacity (i.e. financial and human resources [HR]) to ineffective communication. According to the quantitative investigation, respondents were not sure whether there was an alignment between the corporate- and business-level strategies of their public entities, which would have a positive influence on overall organisational performance or not. There was only one entity for which right from the beginning, the businesslevel strategy was not aligned with that of the parent department simply because of its incorrect registration as a $3 C$ and not as a 3D entity. Otherwise for all the other entities, on paper the two-level strategies were aligned, but the alignment was not implemented. For instance, for one entity, comparing the defined overall business scope and purpose of the entity to the business-level strategies, the relationship between the twolevel strategies was good because the name descriptions of the three core business units in the public entity were in line with the broad business scope and mandate as defined by the parent department, but the problem was with the implementation.

\section{Alignment gaps between the two-level strategies in public entities, why they exist and how they can be minimised}

According to the qualitative investigation, alignment gaps exist for the following reasons:

- lack of capacity (HR and finance)

- lack of communication within the entities

- lack of impact assessments to assess the effectiveness of service delivery programmes

- some entities do not know or are not sure of where they exactly fall in terms of administration, and parent departments cannot clarify this because they lack the legal interpretations

- duplication of key projects and functions; furthermore, having parallel structures at the departments and unclear link between performance targets, the key performance areas (KPA) and the indicators

- flexibility challenges in the public entities pertaining to the execution of the service delivery mandates.

To minimise the gaps in the alignment of the two-level strategies, the issues listed above must be sorted out. In addition, government should revisit the funding model used to fund the entities to consider the vastness of a province and not only the population size; strong research units are needed; rationalisation, merging some entities and parent departments to assist doing some functions on behalf of the entities, etc. But most importantly, parent departments must provide adequate financial and HRs.

TABLE 1: Strategy alignment and organisational performance.

\begin{tabular}{lcccccccc}
\hline Source & Sum of squares & $d f$ & Mean square & Coefficient & Standard error & $t$ & Prob. & 95\% confidence interval \\
\cline { 3 - 8 } & & & & & & Upper \\
\hline Model & 262.978 & 2 & 131.489 & - & - & - & - \\
Residual & 11.800 & 26 & 0.454 & - & - & - & - \\
Total & 274.778 & 28 & 9.813 & - & - & - & - \\
Strategy alignment & - & - & - & 0.624 & 0.263 & 2.37 & 0.025 \\
Leadership & - & - & - & 0.623 & 0.211 & 2.95 & 0.007 \\
\hline
\end{tabular}

Note: Number of obs. $=28$.

Prob $>F=0.000 ; F(2.26)=289.73 ; R^{2}=0.957 ; \mathrm{Adj} . R^{2}=0.954$. 
In the quantitative investigation, the respondents disagreed that the public entities had financial resources to implement their strategies, thereby resulting in not meeting their service delivery and financial performance objectives, and that the public entities had human capital resources to implement their strategies, resulting in not meeting their service delivery and achieving financial performance objectives. These findings were supported by the documentary analysis.

\section{The extent of, if any, the alignment gaps exist between} the two-level strategies in South Africa public entities

There are many gaps between the business strategies and corporate strategies, considering what is actually happening on the ground. Public entities cannot implement their strategies for many reasons as mentioned above. The following are some of the misalignments or gaps that exit between the two-level strategies:

- Entities' financial and HRs are being used and managed by parent departments

- Functions and projects are being duplicated.

The contribution of alignment of corporate- and businesslevel strategies to the improvement of organisational performance in public entities

The alignment gaps between the corporate- and businesslevel strategies need to be rectified for the alignment to contribute to the improvement of organisational performance in public entities. All the issues that cause the gaps in the alignment must be addressed. The recommendations of how this can be done are listed in How the Alignment Between Corporate-level and Business-level Strategies Can Contribute to the Improvement of Organisational Performance in South Africa Public Entities section.

\section{Discussion}

\section{The relationship between corporate- and business-level strategies in public entities}

Public entities have both a corporate strategy and a businesslevel strategy, which are guided by and are in line with SA's Acts, the national sector strategies and official master plans governing the mandates and scope of the industries and the business entities. The strategic plans of the public entities are also guided by these national sector strategies and official master plans. This research has found that on paper, most entities have their business-level strategies aligned to the corporate strategies. The problem however, is that practically, the alignment of the two-level strategies and strategy implementation do not exist because of HR and finance capacity challenges; leadership issues, which include ineffective boards, supporting Mbo and Adjasi (2017a:960, 2017b:405); and working in isolation with no effective communication, supporting Monauni (2017:1), Sull et al. (2015:4) and Sull, Sull and Yoder (2018b:130). This is compatible with Ali and Hadi's (2012:265) estimation that about two-thirds of good and well-conceived strategies of organisations are not implemented effectively. This study has found that alignment gaps exist between corporate- and business-level strategies in SA public entities, and provides the reasons why this happens, such as the lack of capacity and ineffective communication, affecting their performance.

\section{Why alignment gaps exist between the two-level strategies in public entities, and how they can be minimised}

The alignment gaps between the two-level strategies in the public entities happen mainly because of the lack of financial and HRs. Generally, performance targets are set according to the available resources and the limitations a public entity has, not strictly according to the mandate and corporate strategy, and hence, the alignment gaps exist. This assertion is consistent with the research contribution of Firmansyah (2015:667), Kogo and Kimencu (2018:132), Sull et al. (2017b:2) as well as Balashova and Gromova (2016:326), regarding the critical internal capabilities and valuable resources of the organisation to achieve its strategic objectives. This study not only determines the relationship between strategy implementation and strategic objectives but also provides reasons for failure of strategy implementation and the misalignment between the corporate- and business-level strategies.

\section{How the alignment in corporate- and business-level strategies can improve organisational performance in public entities}

For the alignment between the corporate strategies and business strategies to be real and be able to improve organisational performance, the entities must have adequate financial and HRs (including the right requisite skills), support from the parent departments as well as the flexibility they need to be able to respond fast enough to the needs of the markets. This implies that even if there is alignment between the two-level strategies, so long as a public entity does not have enough resources, support from the parent department and the flexibility it needs, it will not be able to implement its strategies in order to deliver on its mandate and perform optimally to achieve its objectives. To minimise the alignment gaps between the two-level strategies, the recommendations that are provided in this article should be implemented. If these issues are addressed, the alignment of corporate- and business-level strategies will help to improve the organisational performance in public entities. Most importantly, finance and resources, duplication of projects and programmes need urgent attention.

\section{Conclusion}

\section{Perceptions of executives in public entities and the relationship between corporate- and business-level strategies in public entities in South Africa}

The alignment between the corporate strategies and business-level strategies is important because it impacts the organisational performance. In this study, it has been found that the many challenges the public entities have, including 
human capital inadequacy or/and lack of HRs, bring about strategy misalignment, which in turn affects organisational performance negatively because then, the entities cannot deliver on their mandate by achieving their strategic objectives.

The implementation of the business strategies is a big issue. Because performance targets are not strictly set according to the mandate and corporate strategies - reasons being that the public entities have challenges and limitations including finance and HRs, this results in having alignment gaps, hence poor strategy implementation and an unsatisfactory organisational performance.

To reiterate, public entities have both corporate- and businesslevel strategies, which are guided by the corresponding SA's Acts, the national sector strategies and official master plans governing the mandates and scope of the industries and the business entities. On this article, most entities have their business-level strategies aligned to the corporate strategies, and so, the relationship appears to be good; but practically, on the ground, the relationship is not good.

\section{Reasons why alignment gaps exist between corporate- and business-level strategies}

Gaps in the alignment between the corporate- and businesslevel strategies of the public entities exist for reasons such as: lack of capacity (i.e. finance and HRs) and not being sure of where a public entity exactly falls in terms of administration.

\section{How the alignment between corporate-level and business-level strategies can contribute to the improvement of organisational performance in South Africa public entities}

For the alignment between the business strategy and corporate strategy to contribute and improve organisational performance, the entities must have adequate financial and HRs (including the right requisite skills); support from the parent departments; the flexibility they need to be able to respond fast enough to the needs of the markets; and all the other issues mentioned above must be sorted out. If these issues are addressed, there will be alignment between corporate- and business-level strategies, which will then contribute and improve organisational performance in public entities. It was found that there is a lack of positive relationship between the alignment of corporate-level and business-level strategies, and the organisational performance of SA public entities.

\section{Strengths and limitations}

The case study design was appropriate because the objective of the study was to investigate a contemporary event, where it was not necessary to control behavioural events or variables. This kind of design was desirable as the intent of the research was description and theory testing. The multiplecase design allowed for cross-case analysis and the extension of theory. Qualitative researchers develop a description of the context in which the behaviour takes place and attempt to see the behaviour from the position of its originator. Such contextual understanding is unlikely to be achieved without direct, first-hand knowledge of a research setting. The study was also validated by triangulating it using the quantitative methods. The limitations of the case study included a lack of controllability, deductibility, repeatability and generalisability, where the latter two limitations stemmed largely from the lack of power to randomise.

\section{Recommendations}

In accordance with the research objective of this study, the following are the recommendations:

- Capacity challenges (HR and finance) in the public entities should be attended to

- Duplication of functions, projects and programmes in the public entities must be eliminated

- Regular impact assessments of the public entities should be performed

- Legality issues affecting the public entities should be clarified and attended to

- Communication between parent and public entities should be improved.

\section{Acknowledgements}

I wish to thank the following professors: my promoter, Dr Werner Vermeulen, for his critical coaching and support in all aspects of the research project; Prof. Helena van Zyl, Director of the UFS Business School and Prof. M.J. Crous for their assistance; as well as Mrs. Edna Cox, for her dedication and passion in giving the administrative support when I needed it the most.

\section{Competing interests}

The author declares that he has no financial or personal relationships that may have inappropriately influenced him in writing this research article.

\section{Author's contributions}

M.M.G. is the sole author of this research article.

\section{Funding information}

This research received no specific grant from any funding agency in the public, commercial or not-for-profit sectors.

\section{Data availability}

Data sharing is not applicable to this article as no new data were created or analysed in this study.

\section{Disclaimer}

The views and opinions expressed in this article are those of the author and do not necessarily reflect the official policy or position of any affiliated agency of the author. 


\section{References}

Ali, M. \& Hadi, A., 2012, 'Surveying and identifying the factors affecting successful implementation of business strategies in companies of Fars province industria town: Case study - Companies of food industries', International Journal of Business and Social Science 3(1), 265-272.

Andrews, R.G.A., Boyne, K.J., Meier, L.J., O’Toole, J.R. \& Walker, R.M., 2012, 'Vertical strategic alignment and public performance', Public Administration Journal 90(1), 77-98. https://doi.org/10.1111/j.1467-9299.2011.01938.x

Association of Chartered Certified Accountants (ACCA), 2012, Governance, control and risk, ACCA International Office, London.

Balashova, E.S. \& Gromova, E.A., 2016, 'Resource-based view as a perspective management model in Russian reality', Problems and Perspectives in Management 14(2-2), 325-330. https://doi.org/10.21511/ppm.14(2-2).2016.08

Bikson, T.K., 1991, 'A response to Attewell and rule', in K.L. Kraemer (ed.), The information systems research challenge: Survey research methods, pp. 323-334, Harvard Business School Press, Boston, MA.

Bowman, E.H. \& Helfat, C.E., 2001, 'Does corporate strategy matter?', Strategic Management Journal 22(1), 1-23. https://doi.org/10.1002/1097-0266(200101) 22:1\%3C1::AID-SMJ143\%3E3.0.CO;2-T

Carvalho, M.P.U., Francisco, U.P. \& Paulo, S.F., 2017, 'Are competencies and corporate strategy aligned? An exploratory study in Brazilian steel mills', Revista Ibero Americana de Estratégia 16(4), 117-132. https://doi.org/10.5585/riae.v16i4.2536

Coulter, M., 2002, Strategic management in action, Prentice-Hall Inc., Upper Saddle River, NJ.

Creswell, J.W., 2008, The selection of a research design, Sage, Thousand Oaks, CA.

Cristian-Liviu, V., 2013, 'Organisational culture and strategy: How does it work? Empirical research', Annals of the University of Oradea 1(1), 1690-1697.

Doukas, J.A. \& Kan, O.B., 2008, 'Investment decisions and internal capital markets: Evidence from acquisitions', Journal of Banking and Finance 32:1, 484-498.

Firmansyah, R., 2015, 'Building value creation through the resources, new product development and competitive strategy to increase business performance: A study at Indonesia telecommunication industry', International Journal of Education and Research 3(2), 667-676.

Galvin, P., Rice, J. \& Liao, T., 2014, 'Applying a Darwinian model to the dynamic capabilities view: Insights and issues', Journal of Management and Organisation 20(2), 250-263.

Giachetti, C., 2012, 'A resource-based perspective on the relationship between service diversification and firm performance: evidence from Italian facility management diversification and firm performance: evidence from Italian facility man
firms', Journal of Business Economics and Management 13(3), 567-585.

Gold, M., Campbell, A. \& Alexander, M., 1994, Corporate level strategy: Creating value in the multibusiness company, 1st edn., John Wiley \& Sons, New York, NY.

Grant, R.M., 2010, Contemporary strategy analysis, John Wiley \& Sons, Sussex.

Gutek, B.A., 1991, 'Commentary on survey and other methodologies applied to IT impact research: Experiences from a comparative study of business computing', in K.L. Kraemer (ed.), The information systems research challenge: Survey research methods, pp. 317-322, Harvard Business School Press, Boston, MA.

Higgins, J.M., 2005, 'The eight "S"s successful strategy execution', Journal of Change Management 5(1), 3-13. https://doi.org/10.1080/14697010500036064

Hough, J., Thompson, A.A. Jr., Strickland, A.J. \& Gamble, J.E., 2008, Crafting and executing strategy: Texts, readings and cases, McGraw-Hill, Berkshire.

Ireland, R.D., Hoskisson, R.E. \& Hitt, M.A., 2011, The management of strategy, 9th edn., South-Western Higher Education, Hampshire.

Ito, K. \& Souissi, M., 2012, 'Managerial accounting as a tool for corporate strategy: Synergy creation and Synergy inhibition', Journal of International Business Research 11(2), 63-72.

Jooste, C.J., Strydom, J.W., Berndt, A. \& Du-Plessis, P.J., 2008, Applied strategic marketing, 3rd edn., Heinemann Publishers, Johannesburg.

Kogo, P.K. \& Kimencu, L., 2018, 'Organisational capabilities and performance of insurance companies in Nairobi city county, Kenya', International Academic Journal of Human Resource and Business Administration 3(1), 126-149.

Lowy, A., 2015, 'The six dilemmas of strategy execution', Strategy and Leadership 43(6), 18-24. https://doi.org/10.1108/SL-07-2015-0062

Martin, J.D. \& Sayrak, A., 2003, 'Corporate diversification and shareholder value: a survey of recent literature', Journal of Corporate Finance 9, 37-57.

Matsusaka, J.G., 2003, 'Corporate diversification, value, maximisation and organisational capabilities', Journal of Business 74(3), 409-431.

Mbo, M. \& Adjasi, C., 2017a, 'Performance of SOEs: Evidence on Botswana Telecommunications Corporation', International Journal of Social Economics 44(7), 960-979. https://doi.org/10.1108/IJSE-01-2016-0005

Mbo, M. \& Adjasi, C., 2017b, 'Drivers of organisational performance in state owned enterprises', International Journal of Productivity and Performance Management 66(3), 405-423. https://doi.org/10.1108/IJPPM-11-2015-0177
Monauni, M., 2017, 'Closing the strategy execution gap through business simulations', Development and Learning in Organizations: An International Journal 31(4), 9-12.

Musuka, P., 2006, 'Alignment of IT strategy with business strategy: Impact on IT effectiveness and business performance', Master's thesis, University of South Africa.

Ostlund, U., Kidd, L., Wengstrom, Y. \& Rowa-Dewar, N., 2011, 'Combining qualitative and quantitative research within mixed method research designs: A methodological review', International Journal of Nursing Studies 48(3), 369-383. https://doi.org/10.1016/j.ijnurstu.2010.10.005

Peng, M.W., Bruton, G.D., Stan, C.V. \& Huang, Y., 2016, 'Theories of the (state-owned) firm', Asia Pacific Journal of Management 33(2), 1-22.https://doi.org/10.1007/ s10490-016-9462-3

Picone, P.M. \& Dagnino, G.B., 2011, 'Conglomerate diversification strategy and corporate performance', PhD thesis, University of Catania.

Porter, M.E., 1980, Competitive strategy, Free Press, New York, NY.

Prasad, D.S., Pradhan, R.P., Gaurav, K., Chatterjee, P.P., Kaur, I., Dash, S. et al., 2018 'Analysing the critical success factors for implementation of sustainable supply chain management: An Indian case study', Decision (Calcutta) 45(1), 1-23. https:// doi.org/10.1007/s40622-017-0171-7

Putnins, T.J., 2015, 'Economics of state-owned enterprises', International Journal of Public Administration 38(11), 815-832. https://doi.org/10.1080/01900692.2014. 982289

Ramaseshan, B., Ishak, A. \& Rabbanee, F.K., 2013, 'The role of marketing managers' commitment and involvement in marketing strategy implementation', Journal of Strategic Marketing 21(6), 465-483. https://doi.org/10.1080/0965254X.2013. 804858

Reitsma, E. \& Hilletofth, P., 2018, 'Critical success factors for ERP system implementation: A user perspective', European Business Review 30(3), 285-310. https://doi.org/10.1108/EBR-04-2017-0075

SA National Treasury, 2016, Budget speech, Government Printer, Pretoria.

Saunders, M., Lewis, P. \& Thornhill, A., 2009, Research methods for business students, Pearson education, Essex.

Schniederjans, M. \& Cao, Q., 2009, 'Alignment of operations strategy, information strategic orientation, and performance: An empirical study', International Journal of Production Research 47(10), 2535-2563. https://doi.org/10.1080/002075 40701673465

Seifzadeh, S.A.P., 2013, 'The role of corporate controls, size and corporate headquarters in the effect of corporate-level strategy and business-level performance', PhD thesis, University of Western Ontario.

Silverman, D., 2000, Doing qualitative research: A practical handbook, Sage, London.

Stan, C.V., Peng, M.W. \& Bruton, G.D., 2014, 'Slack and the performance of stateowned enterprises', Asia Pacific Journal of Management 31(2), 473-495. https:// doi.org/10.1007/s10490-013-9347-7

Sull, D., Homkes, R. \& Sull, C., 2015, 'Why strategy execution unravels and what to do about it: Spotlight on where strategy stumbles', Harvard Business Review 93(3), 57-66.

Sull, D., Turconi, S., Sull, C. \& Yoder, J., 2017a, 'Turning strategy into results', MIT Sloan Management Review 59(3), 1-12.

Sull, D., Turconi, S., Sull, C. \& Yoder, J., 2017b, 'Four logics of corporate strategy', MIT Sloan Management Review, 1-9.

Sull, D., Turconi, S., Sull, C. \& Yoder, J., 2018, 'How to develop strategy for execution', MIT Sloan Management Review 59(2), 130-135.

Torrance, H., 2012, 'Triangulation, respondent validation and democratic participation in mixed methods research', Journal of Mixed Methods Research 6(2), 111-123. https://doi.org/10.1177/1558689812437185

Van Deusen, L.C., Holmes, S., Cohen, A., Restuccia, J., Cramer, I., Shwartz M. et al., 2007, 'Transformational change in health care systems: an organizational model', Health Care Management Review 32(4), 309-320.

Van Riel, C.B.M., 2008, 'Creating a strategically aligned workforce', Corporate Reputation Review Journal 11(4), 351-359. https://doi.org/10.1057/crr. 2008.29

Volberda, H.W., Morgan, R.E., Reinmoeller, P., Hitt, M.A., Ireland, R.D. \& Hoskisson, R.E., 2011, Strategic management concepts and cases: Competitiveness and globalisation, 9th edn., South-Western Higher Education, Hampshire.

Wang, Z., Chen, X. \& Yu, M., 2017, 'Interactive effect of leader-member tie and network centrality on leadership effectiveness', Social Behaviour and Personality 45(7), 1197-1210.

Ying, Y., Deng, P. \& Liu, Y., 2016, 'Strategic flexibility, institutional hardship, and international expansion strategy of Chinese new ventures', China: An International Journal 14(4), 118-130. 